\title{
The CNPFT/EMBRAPA Fruit Breeding Program in Brazil
}

\author{
Maria C.B. Raseira', Bonifacio H. Nakasu', Alverides M. Santos', Joel F. Fortes', \\ Olinda Maria Martins ${ }^{2}$, Ailton Raseira ${ }^{3}$, and João Bernardi ${ }^{3}$ \\ Empresa Brasileira de Pesquisa Agropecuaria/Centro Nacional de Pesquisa de Fruteiras de \\ Clima Temperado, Caixa Postal 403 - 96001 - Pelotas, RS, Brazil
}

The National Research Center of Temperate Fruit Crops (CNPFT) (Fig. 1) is located at Pelotas, Rio Grande do Sul (RS), and is part of the Brazilian Agricultural Research Enterprise (EMBRAPA). The center has three experimental areas. The main unit, with 290 ha and $15,000 \mathrm{~m}^{2}$ of construction, includes offices; laboratories of tissue culture, electrophoresis, plant breeding, entomology, plant pathology, immunology, plant nutrition, postharvest physiology, and food science; a library; and screenhouses. The second area (151 ha) is $10 \mathrm{~km}$ from the main unit and is used for the production of seeds and scions and for other activities related to the breeding programs. The third experimental area (114 ha) is located in Vacaria, in the mountain region of RS, the second most important area for apple production in Brazil. Experiments with apples (Malus domestica Borkh.), pears (Pyrus communis L.), prunes (Prunus domestica L.), and collections of other fruit species are conducted in this unit.

\section{HISTORY AND OBJECTIVES}

The CNPFT was established 23 Jan. 1984 with the responsibility of coordinating the National Research Program of Temperate Fruits, which includes activities of other research institutions (e.g., state enterprises, universities) in eight states: RS, Santa $\mathrm{Ca}$ tarina, Paraná, São Paula, Goirás, Minas Gerais, Espírito Santo, and Pernambuco. This program consists of $>100$ research projects on diverse crops, 81 of them being devel-

The center also has a program $(\approx 20$ research projects) with regionally important agus officinalis L.), carrots (Daucus carota L.), garlic (Allium sativum L.), onion (Allium cepa L.), potato (Solanum tuberosum L.), sweetpotato [Ipomoea batatas (L.) Lam.], and tomato (Lycopersicon esculentum Miller).

Received for publication 12 Sept. 1991. Accepted for publication 18 Mar. 1992. We thank James N. Moore for reviewing the text. The cost of publishing this paper was defrayed in part by the payment of page charges. Under postal regulations this paper therefore must be hereby marked $a d$ vertisement solely to indicate this fact.

'Fruit Breeder.

Plant Pathologist. oped by the CNPFT research staff. vegetable crops, such as asparagus (Aspar-

${ }^{3}$ Horticulturist.
Among the temperate fruit crops, the center gives priority to studies with apple, blackberry (Rubus sp.), fig (Ficus carica L.), nectarine (Prunus persica var. nucipersica Borkh.), peach (Prunus persica L. Batsch), pear [Pyrus communis and Pyrus pyrifolia (Burn.) Nakai], plum (Prunus salicina Lindl.), prune (Prunus domestica L.), strawberry (Frugaria $\times$ ananassa L. Duch.), and native fruit species, such as brazilian guava (Psidium cattleyanum Sab.), feijoa (Feijoa sellowiana Berg), and brazilian cherry (Eugenia uniflora $\mathrm{L}$.).

Collections of cultivars of blueberry (Vaccinium ashei Beade), cherry ( $P$. avium L., P. cerasus L.), kiwi [Actinidia deliciosa (A. Chev.) C.F. Liong et A.R. Ferguson], pecan [Carya illinoinensis (Wangenh.) K. Koch], and raspberry ( $R$. islaens L.) are maintained and evaluated.

Before 1984, research in fruits and vegetable crops was conducted at the Experiment Station of Cascata, Ministry of Agriculture, which gave rise to the State Unity of Agricultural Research of Cascata (UEPAE de Cascata) that evolved to the present National Center.

Breeding programs, germplasm banks, research on biological control of diseases and pests, integrated pest and weed control, or-

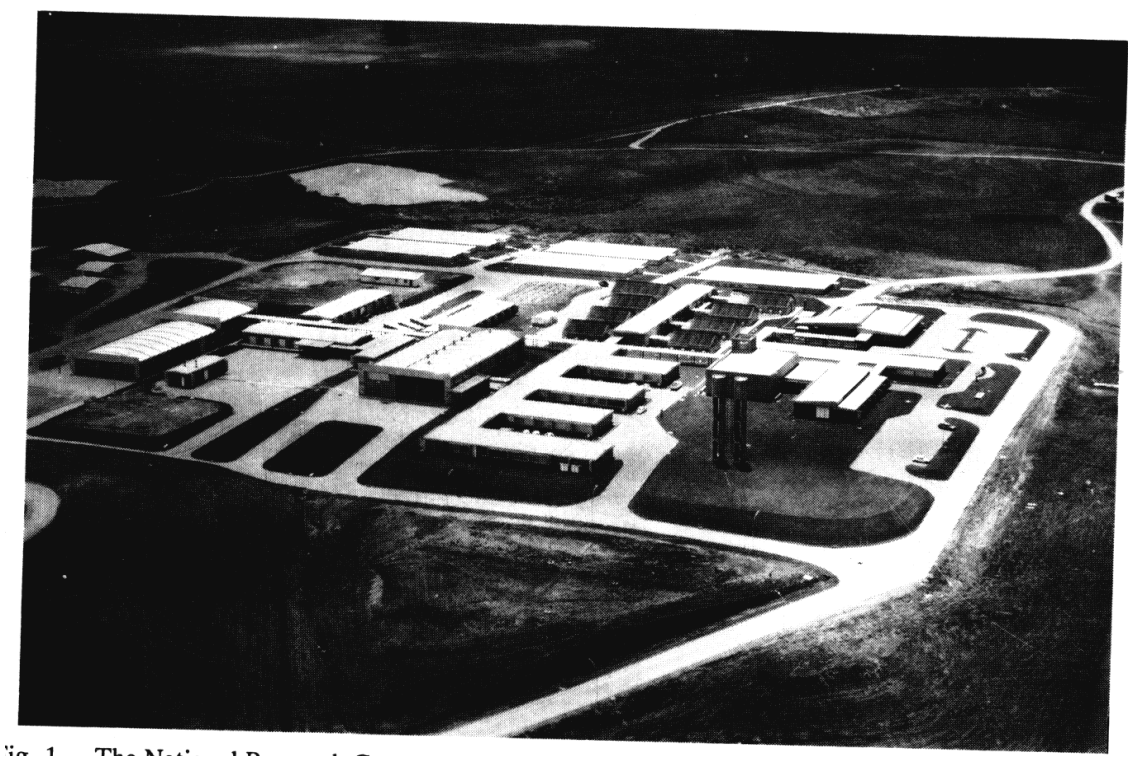

Fig. 1. The National Research Center of Temperate Fruit Crops of The Brazilian Agricultural Research Enterprise (CNPFT/EMBRAPA).

\section{GERMPLASM BANKS} persica and $P$. salicina. $>170$ entrys.

\section{FRUIT BREEDING PROGRAM} search Program are with apples.

Peach chard management, electrophoresis, and postharvest physiology and storage of fruits are some of the priority areas of the CNPFT.

The center has two active germplasm banks: Prunoideas and asparagus. The bank of Prunoideas has $>800$ accessions, mainly $P$.

The germplasm bank of asparagus has

The fruit breeding program at Pelotas began in the late 1950 s with peach. At that time, peach was the most important fruit crop for the southern region of Brazil. By the 1970s, the apple industry had become so large and important that at present the majority of projects of the National Temperate Fruit Re-

Breeding programs for pear, plum, and small fruits, and recently the native species, are increasing in importance. Many cultivars have been released by the CNPFT (Table 1).

Brazil has $\approx 22,800$ ha of peach orchards 
(IBGE, 1989), of which $\approx 12,000$ ha are located in RS.

In 1963 (Feliciano, 1979), when the breeding program officially began in Pelotas, only two cultivars were grown in RS: 'Aldrighi', a seed-propagated clingstone, and 'Delicioso', a white-flesh cultivar for fresh market. The peach harvesting period was $\approx 15$ days long.

A few hundred clones were selected from seedling plants in the peach area of Pelotas, since the growers did not use asexual propagation at the time, and $\approx 200$ cultivars and selections were introduced from Europe and the United States. Before then, in 1957, thousands of open-pollinated and hybrid seeds were collected in Florida, Georgia, North Carolina, Maryland, California, and particularly New Jersey (Feliciano, 1979).

At the beginning of the breeding program, top priorities were the expansion of the harvesting period, regional adaptation, fruit quality, and productivity. After the development and release of $>40$ peach cultivars, this program has provided the possibility of a peach harvest period of 100 days.

Today, the major goals are to obtain cultivars resistant to diseases, mainly to brown rot [Monilinia fructicola (Wint.) Honey] and bacterial spot [Xanthomonas campestris pv. pruni (Smith) Dye], to increase fruit size and improve flesh firmness and quality in general, and to provide fruits that can be transported to distant markets. Dual-purpose fruits, suitable either for fresh market or processing, are also desirable.

Some of the major problems that CNPFT research is addressing are related to mild winters and high humidity. In the southern region of Brazil, where peaches are grown, annual accumulated chilling hours range from 50 to $650 \mathrm{~h}$. Areas with fewest chilling hours grow cultivars released by the Agronomic Institute of Campinas (IAC), São Paulo, with lower chilling requirements. In the states of RS, Santa Catarina, and Paraná, at least $90 \%$ of the commercial cultivars have been released by the Center in Pelotas, RS.

Spring frost is quite common in some areas as well as rain during bloom and ripening, which results in frequent frost damage and disease problems.

Some low-chilling genotypes have been identified that require a high heat accumulation for blooming, thereby escaping frost damage. Sources of disease resistance are being sought in the germplasm bank and also abroad to incorporate this character in commercial cultivars.

'Bolinha', a release of the CNPPT, and 'Kakamas', a South African cultivar, have some degree of horizontal resistance to brown rot. Local cultivars such as 'Convênio', 'Gaucho', and 'Cristal Taquari' are being tested as sources of bacterial spot resistance due to their behavior in the field.

About 10,000 seedlings originating from controlled hybridizations are evaluated each year. Several selections of peach and nectarine are being evaluated in advanced tests for possible future release.

\section{Apple}

The apple industry in Brazil became commercially important by the 1970 s. More than 28,000 ha are planted to apples, with 10,600 ha in RS alone (Agapomi, 1990). In the past 12 years, national production has increased from 14,000 to $392,000 \mathrm{t}$ (Nakasu, 1990). The apple industry has stimulated economic development in a large area, creating thousands of jobs directly or in related areas, such as chemical industries, packinghouses, manufacture of fertilizers and machinery, etc.

The major objectives of the breeding program are the development of better-adapted cultivars, scab resistance [Venturia inaequalis (Cooke) Wint.], good quality, and desirably long storage life. The development of early ripening cultivars (before 'Gala') and those with fruits ripening with 'Golden Delicious', i.e., between 'Gala' and 'Fuji', and with bright red stripes are also among the major goals.

Two cultivars have been released by the CNPFT, both yellow-skinned apples, but now are obsolete. The first, 'BR-1', was released because of its productivity, size, adaptation, and, especially, earliness. However, the quality was not good. 'BR-2' produced goodquality apples, but the production was not consistently high and the local market prefers red apples.

From 20,000 to 30,000 seeds originating from controlled crosses are planted each year, and seedlings are submitted to a screening for scab resistance.

\section{Pear}

Until 1968, Brazil was one of the main pear producers in South America, averaging $55,000 \mathrm{t} \cdot$ year $^{-1}$. Pear production has now decreased to $\approx 20,000$ t, due to susceptibility to diseases, lack of adapted cultivars, and use of an unsuitable rootstock. With the introduction of $P$. calleryana D-6 as rootstock and some European and Asiatic scion culti- vars, the pear industry is expected to expand very soon (Nakasu and Leite, 1989).

In addition to breeding for new cultivars adapted to the conditions of southern Brazil and with resistance to scab ( $V$. pirina Aderth.) and leaf spot (Fabraea maculata Atk.), the CNPFT provides cultivar recommendations to growers, based mainly on introductions observed in several collections, which are adapted to areas of 400 to 800 chilling hours.

For the mild winter areas, 'Carrick', 'Tenn', 'Barlett', 'Garber', 'Seleta', and the Asiatic-type pears such as 'Kosui', 'Ya-Li', 'Hosui', and 'Okusankichi' can be successfully cultivated. Some selections that originated from the breeding of the CNPFTPirus 1, 3, and 9-are also promising.

For the areas of higher chilling accumulation, 'Packham's Triumph', 'Africana' 'Highland', and the Asiatic types 'Século XX' and 'Hosui' are recommended, among others.

\section{Plum}

Plum culture in Brazil has been seriously threatened by leaf scald, a disease caused by rickettsia-like bacteria. In the last 5 years, clean material was released by CNPFT/RMBRAPA, and the plum industry is being reestablished.

In some areas of RS and Santa Catarina, bacterial spot [Xanthomonas campestris pv. pruni (Smith) Dye] is a limiting factor. Resistance to both bacterial and leaf scald are primary objectives in the program, in addition to quality and adaptation (Nakasu et al., 1981).

Compatibility among Japanese cultivars for satisfactory production has been studied under local conditions (de Carvalho and Raseira, 1992).

'Reubennel', 'Amarelinha', 'Rosa Mineira', 'Methley', 'Wade', 'Santa Rosa', 'Catari', 'Golden Japan', 'Pluma 7', and a

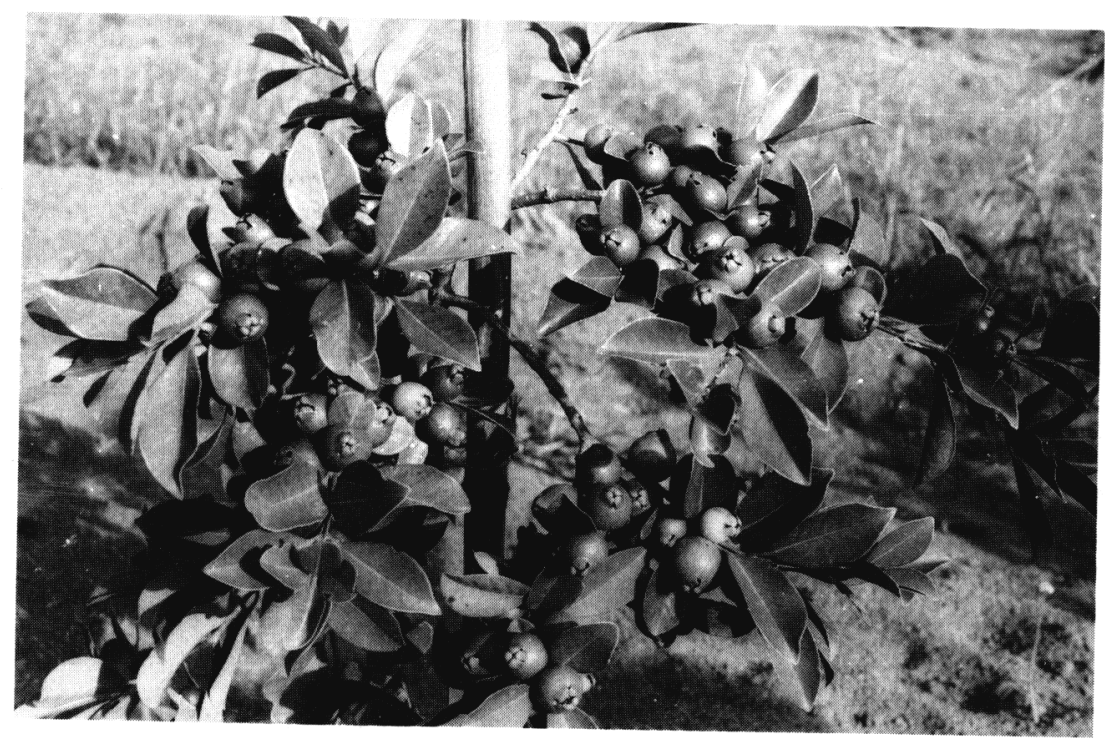

Fig. 2. A seedling of Psidium cattleyanum Sab., showing the high productivity. 
Table 1. Fruit cultivars released by the CNPFT/EMBRAPA.

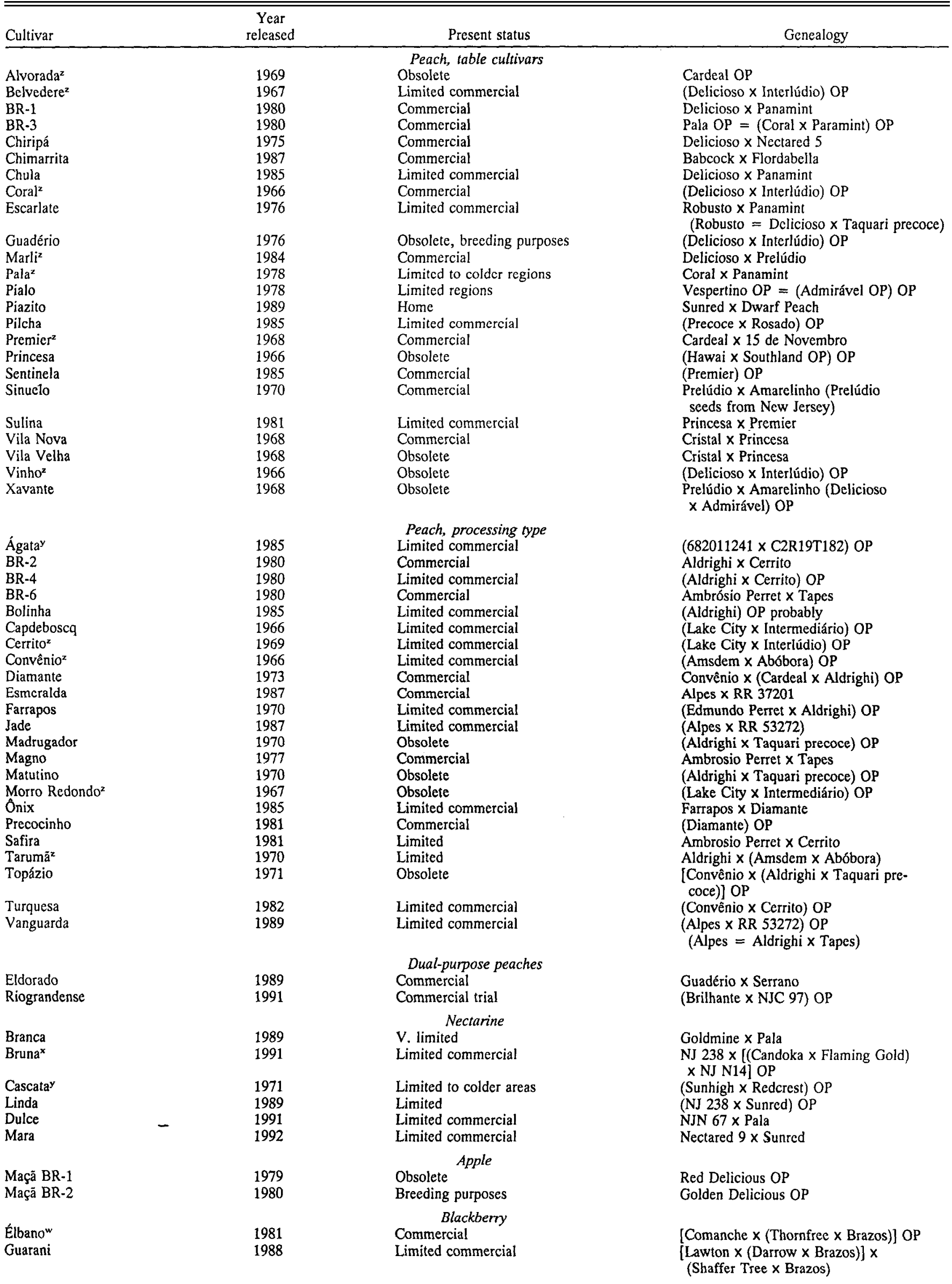


Table 1. Continued.

\begin{tabular}{lcll}
\hline \hline Cultivar & $\begin{array}{c}\text { Year } \\
\text { released }\end{array}$ & Present status & \multicolumn{1}{c}{ Genealogy } \\
\hline Tupi & 1988 & Limited commercial & Uruguai $\times$ Comanche \\
Negrita & 1983 & Limited commercial & Comanche $\times$ (Thornfree $\times$ Brazos) \\
Caingang & 1991 & Limited commercial & Cherokee $\times$ (Shaffer Tree $\times$ Brazos) \\
& & Strawberry & Cambridge OP \\
Princesa & 1958 & Commercial & Konwoy clone sclection \\
Konwoy-Cascata & 1981 & Commercial &
\end{tabular}

Originated from a joint program with the State Dept. of Agriculture-Estação Fitoténica de Taquari.

'Seeds received from L.F. Hough, Rutgers Univ., New Brunswick, N.J.

'Joint release with IAPAR (Agronomic Institute of Paraná).

"Joint release with the Univ. of Arkansas, Fayetteville.

selection from the CNPFT Program, AM-4, are among the best for areas of 300 to 400 hours of chilling. In the mountain region, where $>700$ hours of chilling accumulate, 'Ozark Premier', 'Burbank', and the European types such as 'D'Agen', 'President', and 'Stanley' are recommended. Some of the cultivars listed above are susceptible to bacterial spot and are limited to small areas.

A screening procedure for bacterial spot is being studied. Besides the European cultivars, the Japanese type 'Bruce' and 'Burbank' are among the least susceptible.

\section{Strawberry}

The release of 'Princesa' and 'KonvoyCascata', for fresh market and processing, respectively, are the main contributions of the strawberry breeding program of the CNPFT. High productivity, disease resistance, uniform red fruit pigmentation, and firmness of the fruit flesh are some of the objectives being pursued.

\section{Blackberry}

The blackberry industry in Brazil is not large, but it is very promising. The center started a breeding program in the mid-1970s with the cooperation of J.N. Moore of the Univ. of Arkansas. The cultivars Ebano, Negrita, Tupi, and Guarani are results of this program. The U.S. cultivars Brazos, Comanche, Cherokee, and Cheyenne are also being grown successfully in the southern states of Brazil.

The major goal of the CNPFT blackberry breeding program is the development of cultivars that are adapted to local conditions, do not overlap in harvest with strawberries and peaches, and have erect, thornless canes producing firm, sweet fruits.

\section{Native fruits}

The native fruit species are being collected to preserve the germplasm. However, three species, all belonging to the Mirtaceae family, are the subject of more intensive work: F. sellowiana, E. uniflora, and Psidium sp. (possibly $P$. cattleyanum) (Fig. 2). Seeds of selected clones of these species, found in woods, fields, or backyards, have been collected. Between 2000 and 4000 seedlings of each species are grown at the CNPFT and are being selected for fruit size, quality, firmness, productivity, seed size, and high ratio between edible and nonedible portions.

Some selected clones have oustanding qualities, and propagation is being conducted for those. Parallel studies on pollen formation and viability are being conducted to provide information for use in future hybridizations. Cultural practices and propagation trials are also underway.

\section{Other fruit species}

The CNPFT maintains collections of quince (Cydonia oblonga Mill.), pecan, cherry, blueberry, fig, and kiwi fruit to observe the potential of those species in the region. The most promising ones will be studied further.

The researchers of the CNPFT are very interested in increasing the exchange of germplasm and information with other institutions that have programs with similar objectives.

\section{Literature Cited}

Agapomi, 1990. Estudo e sugestões sobre a maçã no Rio Grande do Sul. no. 68. p. 4-5.

de Carvalho, T.C.P. and M. do C.B. Raseira 1992. Compatibility among plum cultivars adapted to southern Brazil. Fruit Var. J. 46(1):28-35.

Feliciano, A.J. 1979. Melhoramento genético do pessegueiro. Congresso Brasileiro de Fruticultura, 3, Pelotas, 1979. Anais...Pelotas. Sociedade Brasileira de Fruticultura, 1979. p. 12591268.

IBGE. 1989. Institute Brasileiro de Geografia e Estatistica (Brazilian Institute of Geography and Statistics). Anufirio Estatistico.

Nakasu, B.H. 1992. Temperate zone production in the tropics and subtropics: South America. Acta Hort. 296:231-240.

Nakasu, B.H., M. do C. Bassols, and A.J. Feliciano. 1981. Temperate fruit breeding in Brazil. Fruit Var. J. 35(4):114-122.

Nakasu, B.H. and D.L. Leite. 1989. Indicação de porta-enxerto e cultivares para pereira para o sul do Brasil. Horti Sul 7(2):20-14. 